\title{
LANDSLIDE SUSCEPTIBILITY MAPPING OF THE NORTHEASTERN PART OF ACHAIA PREFECTUREUSING ANALYTICAL HIERARCHICAL PROCESS AND GIS TECHNIQUES
}

\author{
Rozos D. ${ }^{1}$, Bathrellos D. G. ${ }^{2}$, Skilodimou D. H. ${ }^{2}$ \\ ${ }^{1}$ Department of Geological Science, School of Mining and Metallurgical Engineering, NTUA, \\ 9 Heroon Polytechniou str, 15780 Zografou Athens, Greece, rozos@metal.ntua.gr \\ ${ }^{2}$ Department of Geography \& Climatology, Faculty of Geology \& Geoenvironment, \\ National \& Kapodistrian University of Athens, University Campus, Zografou, 15784 Athens, Greece, \\ gbathellos@geol.uoa.gr,hskilodimou@geol.uoa.gr.
}

\begin{abstract}
Landslides are one of the most frequent and disastrous natural hazards worldwide. Thus, the need of landslide susceptibility maps is of primary importance as they are both a useful tool for the land use planning and a necessary step for future development activities. This paper presents an integrated technique of analytical hierarchical process (AHP) and geographic information system (GIS) to create a landslide susceptibility map of the NE part of Achaia prefecture. The study area mainly consists of Neogene deposits and it is a part of the Corinthian graben, which characterized by intense neotectonic activity. Therefore, it is affected by many slope movements that usually cause serious damages in inhabitant areas and road networks. Based on field survey data analysis six parameters were chosen as major parameters that influence the stability of slopes to the direction of landslide manifestation. The AHP method identifies both the rate of the individual classes, and the weight of each factor. Spatial layers with their corresponding rates and weights were linearly combined to prepare the landslide susceptibility map, which includes four zones of slope movement's susceptibility, namely a low, a moderate a high and a very high zone. The evaluation and final confirmation of the map was based on a great number of recorded landslides in the area.
\end{abstract}

Key words: landslide susceptibility map, GIS, AHP method, Achaia prefecture, Peloponnesus.

\section{Introduction}

Landslides are among the most frequent and disastrous natural hazards worldwide, connected in many cases with huge economic and social welfare as well as with the loss of human lives. Therefore, as their manifestation has a great influence on population, constructions and environment, the evaluation of sliding risk is very important to their confrontation (Guzzetti et al., 1999). To this direction, landslide susceptibility maps, covering urban and rural areas and depicting sites with graduated risk levels, constitute a valuable tool for better understanding and confronting landslide's effects, but also for allocating areas prone to landslide manifestation (Castellanos et al., 2007). Moreover, they can be used in urban and rural planning and development (Bathrellos et al., 2009).

This study refers to the compilation of a landslide susceptibility map for the NE part of Achaia prefecture using GIS and the Analytical Hierarchy Process (AHP). 
The AHP is multi-objective multi-criteria decision-making methodology (Saaty 1990; 2006) that has been used for compilation of sliding risk maps by many researchers (Ayalew et al., 2004; Komac 2006; Yoshimatsu and Abe 2006; Castellanos et al., 2007; Akgün et al., 2008). This process gives the ability of the correlation both the parameters that cause landslide manifestation and their classes, by using a table in which comparison of every two parameters and their classes is carried out.

Moreover, Geographic Information Systems (GIS) comprise a valuable tool for the compilation of landslide susceptibility maps (Saha et al., 2002; Lan et al., 2004). The use of GIS in such a case gives the advantage of a quick analysis, processing and correlation of a big volume of data.

As a great number of landslide phenomena is manifested in western Greece (Koukis and Rozos, 1982), the NE part of Achaia prefecture, was chosen for this study. This area mainly consists of Neogene deposits and it is a part of the Corinthian graben, which characterized by intensive neotectonic activity. So, it is affected by many slope movements that usually cause serious damages in inhabitant areas and road networks. For the above reasons, various studies have been done in the past regarding landslide examination in the Achaia prefecture (Koukis et al. 1997; Koukis et al. 2005; Sabatakakis et al., 2005; Rozos et al., 2006).

\section{Geological setting}

The North-eastern part of Achaia prefecture (study area), has an expanse of about $226 \mathrm{~km}^{2}$, while its altitude varies from 0 to $1760 \mathrm{~m}$. Formations from three geotectonic zones (Olonos - Pindos, Gavrovo - Tripolis and Ionian) participate in the geological structure of Achaia County. Also, the existence of Corinthian graben, with recent geodynamic evolution in its immediate vicinity, results in an increased seismic activity. Therefore, Achaia is characterized by a complicated geological structure with prevailing tectonic fracturing, as Pindos zone constitutes an extended overthrusted cup on Gavrovo zone formations (Rozos 1989).

The study area is constructed by (Rozos 1989; Koukis and Rozos 1982): (a) Fine-grained to coarse - grained loose Quaternary formations (clays, silts, siltstones and sands), as well as weathering products of older formations. Also, loose deposits of mixed phases, such as clayey silts, siltstones, and sands of various grain size distribution, and grits also present. (b) Coarse-grained loose Quaternary formations (pebbles and gravels of varying sizes with a minimum proportion of fine grained materials), screes and fans. (c) Coarse grained coherent Quaternary formations (polygenic conglomerates, usually of a poor gradation), and slope breccias, but also serni-cohesive conglomerates, sands with a low degree of diagenesis and rocky fragments, with red clay as a cementing material. All Quaternary deposits present a quick alteration of their phases, both vertically and horizontally.

(d) Fine - grained Plio-Pleistocene sediments with a variety of lithological horizons (clayey marls alternating with sands of a varying degree of diagenesis), and/or their mixed phases. (e) Coarse grained Plio-Pleistocene sediments (conglomerates, usually strongly cemented, with pebbles of various and clayey - sandy cementing material). In general Plio-Pleistocene sediments can be subdivided into two main horizons. The lower one consisting of fine-grained facies (alternations of clayey marls, marls, silty sands and weak sandstones) prevails, with a progressive transition upwards to the coarser facies, finally giving coherent conglomerates of a great thickness.

(f) Flysch formations. Their main members are sandstones, siltstones and more rarely grit-conglomerates. They are cyclothematic and strongly folded sediments because of the tectonic action (nappes and upthrusts) and thus, they are in many places covered by weathering mantle of considerable thickness. 


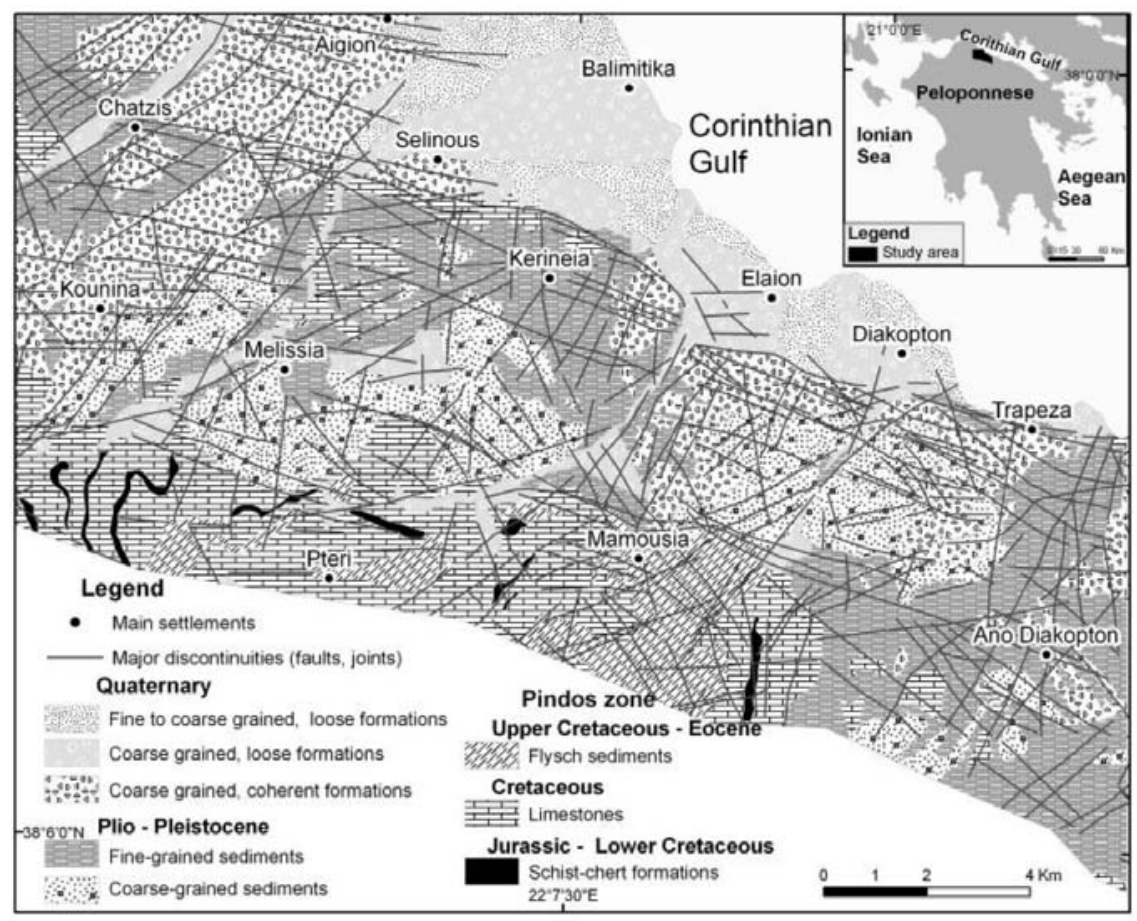

Fig. 1: The simplified geological map and the location map of the study area.

(g) Cretaceous limestones, which are usually moderate to thick-bedded, folded and karstified, with thin intercalations or nodules of silica lumps, but also with rare intercalations of claystones or siltstones.

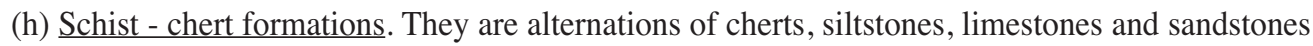
with rare occurrence of volcanic tuffs. Thus, thick weathering mantle is usually formatted, mainly in the cases of the surface occurrence of siltstones.

The surface distribution of the above engineering geological units is given in the map of Fig. 1 .

Regarding the faults and major discontinuities encountered in the area, the examination of air photos and the field work revealed that their distribution and orientation show a rather dispersion, but with domination of these with $\mathrm{N} 70^{\circ}-90^{\circ} \mathrm{E}$ and $\mathrm{N} 30^{\circ}-40^{\circ} \mathrm{W}$ azimuths that are the oldest ones and resulted from the general uplifting of the area, as well as of these with $\mathrm{N} 40^{\circ}-50^{\circ} \mathrm{E}, \mathrm{N} 70^{\circ}-80^{\circ} \mathrm{W}$ and $\mathrm{N} 10^{\circ}-20^{\circ} \mathrm{E}$ azimuths, which are connected with the migration of the Aegean arch (Doutsos et al., 1988).

\section{Methods}

\subsection{Data analysis}

For the application of the AHP method, a data base was firstly created using GIS software ArcGIS v.9.3. Then, all data used for the compilation of the sliding risk map were digitized and the various thematic layers were created. All the data layers were in vector format, transformed in grids with cell size $60 \times 60$ meters. 


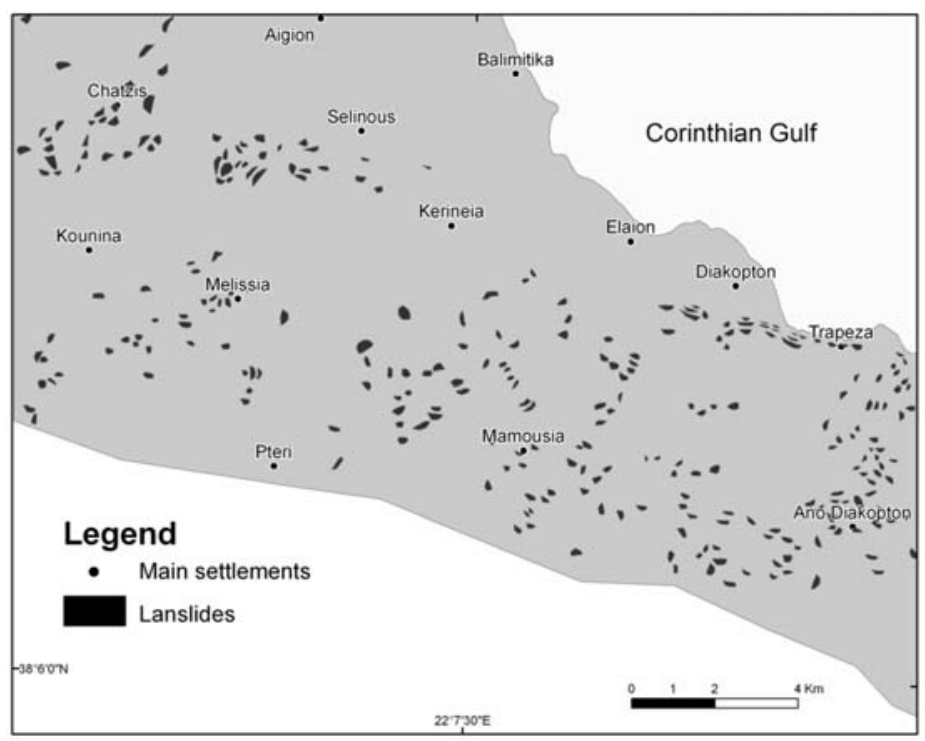

Fig. 2: Landslide events map in the study area.

\section{Landslide inventory map}

Landslide phenomena, for the necessities of the landslide inventory map compilation, were studied and recorded (Fig. 2), using previous works (Rozos 1989), but also field observations in the study area during 2008-2009. Finally, a number of 277 landslide events were recorded, with a varied size from $3.738 \mathrm{~m}^{2}$ to $83.356 \mathrm{~m}^{2}$. These events were engaged for the confirmation and evaluation of the landslide susceptibility map.

Based on the data analysis regarding the 277 landslide events in the area, lithology, distance from tectonic elements, slope's inclination, rainfall, land use, and geometry of main discontinuities, were chosen as major parameters that influence the stability of slopes to the direction of landslide manifestation.

\section{Lithology}

Lithology is one of the most determinative parameters regarding the landslide manifestation. For the study area the classes of lithology have arisen from its geological setting, based on literature (IGME 2005; Rozos 1989) and fieldwork. The distinctive geological formations were digitized and unified according to their engineering geological behaviour, in relation to landslide manifestation. Thus, lithology includes five classes as follows: (a) moderate to thick bedded limestones, (b) thin bedded schist chert formations, (c) Plio-Pleistocene coarse-grained sediments, (d) Cyclothematic formations (Plio-Pleistocene fine-grained sediments and Flysch sediments), (e) Fine, fine-coarse to coarse and loose to semi-coherent Quaternary formations.

\section{Distance from tectonic elements}

The active tectonics in the study area plays an important role in the landslide manifestation. The various tectonic elements were also collected from the same sources as for lithology and fieldwork. All tectonic elements (faults, overthrusts and the rest lineaments) were digitized and buffer zones were formulated around them at distances of $50 \mathrm{~m}, 100 \mathrm{~m}, 150 \mathrm{~m}$ and $200 \mathrm{~m}$. Thus, the classes of the buffer zones are five, namely: (i) the nearest $(0-50 \mathrm{~m})$, (ii) the very near $(51-100 \mathrm{~m})$, (iii) the near (101m-150m), (iv) the moderate distant (151m-200m) and (v) the distant (>200m). 


\section{Slopes' inclination}

The inclination and the aspect of the slopes play a very important role in the manifestation of the landslides because they express the result of the combined influence of many agents (Rozos et al. 2008). The information on slope was obtained from topographical map (scale 1:50,000) developed by Hellenic Military Geographical Service. The grid map of the slopes' inclination was produced by means of the Digital Elevation Model. This map were classified into 5 classes, as follows: (i) $0^{\circ}-5^{\circ}$, (ii) $6^{\circ}-15^{\circ}$, (iii) $16^{\circ}-30^{\circ}$, (iv) $31^{\circ}-45^{\circ}$, and (v) $>45^{\circ}$.

\section{Rainfall}

As it is well known, precipitation is among the most usual triggering factors for landslide manifestation. Rainfall data were derived from four (4) meteorological stations, referred to mean annual precipitation for the period of $1975-2007$. The mean annual precipitation of the area is between 665.98 to $870.93 \mathrm{~mm}$. For the necessities of this study, the precipitation map was produced, using the data of the meteorological stations in the area and applying the Inverse distance weighted (IDW) interpolation method. This map was separated into following classes: (i) $<700 \mathrm{~mm}$, (ii) $701-750 \mathrm{~mm}$, (iii) $751-800 \mathrm{~mm}$, (iv) $801-850 \mathrm{~mm}$, and (v) $>850 \mathrm{~mm}$.

\section{Land use}

The vegetation covering of the study area was taken from CORINE program (Bossard et al. 2000) and was saved as polygon layer. The variations of the vegetation in an area constitute an important parameter affecting the slope failures, as slope stability is very sensitive in changes on vegetation. For the necessities of this study, the land use, which reflects the vegetation covering, was classified into 5 categories as follows: (i) Barren areas, (ii) Urban areas, (iii) Forest areas, (iv) Shrubby areas - Natural grasslands, and (v) Cultivated areas.

\section{Geometry of main discontinuities}

The geometry of the main discontinuities in relation to slope geometry (aspect) is strongly related to the stability of hard soils, and soft rocks that dominate in the study area. Thus, the map of the main discontinuities was compiled using the relevant literature (Rozos 1989; IGME, 2005) and the observations during the fieldwork. The recorded dips and dip directions of the formations were digitized and saved as a map of GIS database. The formations without dip were characterized as "no data formations". In a next step, the map was converted in raster format and combined to the aspect map for the correlation of the dip direction of strata with the slope aspect and classes like "drive against", "drive sideways and vertical" "drive with" were formulated. Furthermore, the "drive with" class was combined with the angle of the slope and another three classes were created. Thus, the overall classes were as follows: (i) Drive against, (ii) Drive sideways and vertical, (iii) Drive with, having a dip of $1^{\circ}-15^{\circ}$, (iv) Drive with, having a dip $16^{\circ}-30^{\circ}$, (v) Drive with, having a dip of $>30^{\circ}$.

All the thematic layers of the instability parameters involved in this study are given in Fig. 3.

\section{The Analytic Hierarchy Process (AHP) method}

As a qualitative inhomogeneity is obvious in between the major parameters affecting slope stability, but also the influence of every one on landslide manifestation varies, the correlation and rating of these parameters and their classes were thought necessary.

This was done using Analytic Hierarchy Process (AHP) method, which includes a table with the numerical values of the binary comparison of the parameters. The binary comparison process is performed using a nine point scale, its numerical values of which with their corresponding level of im- 


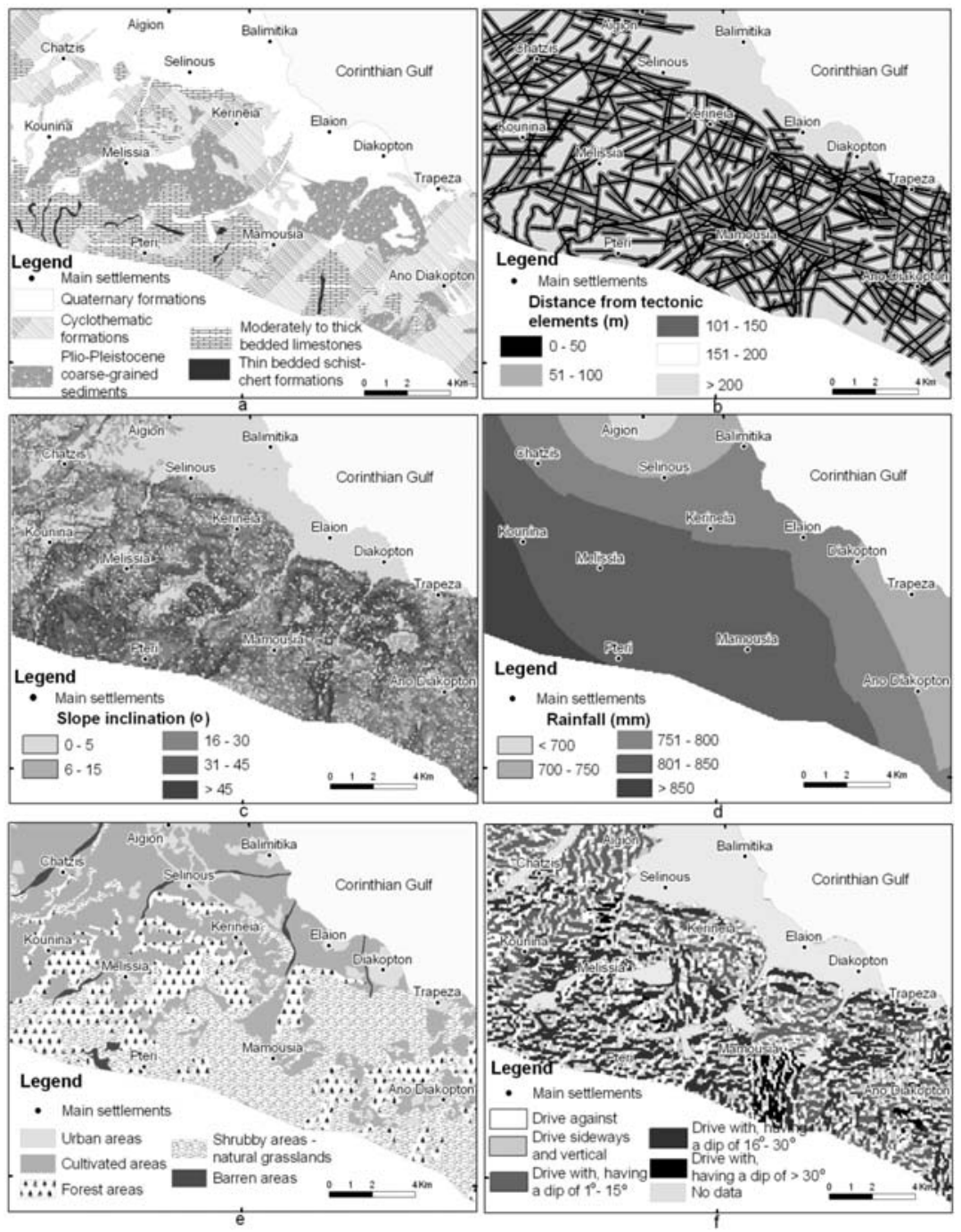

Fig. 3: Thematic maps of the instability parameters involved in this study and their classes. (a) lithology, (b) distance from tectonic elements, (c) slopes' inclination, (d) rainfall, (e) land use and (f) geometry of main discontinuities

portance are: $1=$ equal, $3=$ moderately, $5=$ strongly, $7=$ very strongly, $9=$ extremely $2,4,6,8=$ Intermediate values (Saaty, 1990). In the table used, every factor is weighted in relation to the others, and the derived numerical values, which range from 1/9 to 9 , are placed in the correspondent cells. These values are subjective and represent the relative importance of one factor to the other regarding the adequacy for the seeking purpose. It is obvious that when the binary comparison is applied vice versa, the numerical value is the reciprocal of the initial. Then, the numerical values were normalized by diving each entry in a column by the sum of all the entries in that column, so that they sum up to 1 . Following normalization, the values were averaged across the rows, in order to give the relative importance weight for each parameter. 
The validity of AHP results is checked, by using consistency ratio (CR). This ratio is used in order to avoid the random choice in the AHP table. When CR is less than 0.1 the calculated weighting coefficients are acceptable. If the consistency ratio is higher than 0.1 , a reassessment of judgements in the AHP table is demanded (Saaty, 1990). All the binary comparisons, the eigenvectors, the rates, the weights and the consistency ratio were calculated using the Expert Choice 11 software.

In this study, the instability parameters engaged and their classes were rated, engaging the experience and the field observations. The calculated ratings of the parameters and their various classes from the binary comparison and from CR of every matrix are shown in Table 1.

The aim of this analysis is every pixel of the thematic layers to gain a value, which represents the varied influence to landslide manifestation. For that reason the classes of every parameter were substituted by the numerical values derived from the rating. Next to that, the main parameters were interrelated with the same manner. Therefore, the weighting coefficients values were calculated. The results of the methods' application are shown in Table 2. As can be seen from this table, the parameter with the greater influence on landslide manifestation is slopes' inclination.

\section{Results and discussion}

Finally, and after the application of the AHP, a linear correlation was done between the weighting coefficients of the method and the raster layers of the principal parameters involved. The aim of this correlation was the total estimation of the ratings and thus, the compilation of the final landslide susceptibility map. This linear correlation is given by the formula:

$$
O=\sum_{i=1}^{n} P_{i} W_{i}
$$

Where, $\mathrm{O}=$ the overall score, $\mathrm{n}=$ the number of the parameters, $\mathrm{Pi}=$ the parameter $\mathrm{i}$, and $\mathrm{Wi}=$ the weighting coefficient of the parameter i.

The produced landslide susceptibility map of the study area (Fig. 4) is territorially divided into four landslide susceptibility zones (low, medium, high, and very high), using the Quantile method, which was thought to be the proper one for the necessities of this study.

In this map the percentage extent of the susceptibility zones is $25.13 \%$ for the low zone, $25,22 \%$ for the moderate zone, $24,94 \%$ for the high zone, and $24,71 \%$ for the very high zone. The latter shows the higher territorial extent at the central and southwestern part of study area. The validity of the above map was checked by using the recorded landslides events in the area. For that purpose, the extent of landslides that laid on the distinguished landslide susceptibility zones, were counted using GIS capabilities. The derived percentages are: $9.33 \%$ for low zone, $29.19 \%$ for moderate zone, $28.83 \%$ for high zone, and $32.65 \%$ for very high one. These values, and especially for the last three zones, show a very good correspondence to those derived using AHP method, and thus revealing the validity of AHP application for compilation of landslide susceptibility maps.

\section{Conclusions}

From the above analysis and results, it is clear that a high percentage of the landslides in the study area belong to the zones of high to very high landslide susceptibility in the map, which was compiled, using AHP and GIS capabilities. The AHP is easy applicable, involves no complicated data, and its application is compatible with a GIS. Thus, the AHP and its methodology regarding the rat- 
Table 1. The ratings of the classes of the major parameters used.

\begin{tabular}{|c|c|c|c|c|c|c|}
\hline Parameters & & & & & & Rating \\
\hline Lithology & L1 & L2 & L3 & L4 & L5 & \\
\hline Moderately to thick bedded limestones(L1 ) & 1 & $1 / 2$ & $1 / 3$ & $1 / 5$ & $1 / 7$ & 0.048 \\
\hline Thin bedded schist chert formations(L2) & & 1 & $1 / 2$ & $1 / 4$ & $1 / 6$ & 0.073 \\
\hline Plio-Pleistocene coarse-grained sediments (L3 ) & & & 1 & $1 / 3$ & $1 / 5$ & 0.115 \\
\hline $\begin{array}{l}\text { Quaternary formations fine, fine-coarse to coarse, and loose to } \\
\text { semi-coherent (L4) }\end{array}$ & & & & 1 & $1 / 3$ & 0.253 \\
\hline Plio-Pleistocene fine-grained sediments and Flysch formations(L5 & ) & & & & 1 & 0.510 \\
\hline \multicolumn{7}{|l|}{ Consistency Ratio: 0,03} \\
\hline Distance from Tectonic elements & $\mathrm{T} 1$ & $\mathrm{~T} 2$ & T3 & $\mathrm{T} 4$ & T5 & \\
\hline Nearest $(0-50 \mathrm{~m})-(\mathrm{T} 1)$ & 1 & 2 & 3 & 4 & 5 & 0,409 \\
\hline Very near (51-100m) - (T2) & & 1 & 2 & 3 & 4 & 0,256 \\
\hline Near (101-150m) - (T3) & & & 1 & 3 & 4 & 0,183 \\
\hline Moderate distant (151-200m) - (T4) & & & & 1 & 3 & 0,097 \\
\hline Distant $(>200 m)-(T 5)$ & & & & & 1 & 0,053 \\
\hline \multicolumn{7}{|c|}{ Consistency Ratio: 0,05} \\
\hline Slopes' inclination & S1 & S2 & S3 & S4 & S5 & \\
\hline $0^{\circ}-5^{\circ}(\mathrm{S} 1)$ & 1 & $1 / 3$ & $1 / 4$ & $1 / 5$ & $1 / 7$ & 0,041 \\
\hline $6^{\circ}-15^{\circ}(\mathrm{S} 2)$ & & 1 & $1 / 4$ & $1 / 6$ & $1 / 8$ & 0,060 \\
\hline $16^{\circ}-30^{\circ}(\mathrm{S} 3)$ & & & 1 & $1 / 3$ & $1 / 5$ & 0,135 \\
\hline $31^{\circ}-45^{\circ}(\mathrm{S} 4)$ & & & & 1 & $1 / 3$ & 0,259 \\
\hline$>45^{\circ}(\mathrm{S} 5)$ & & & & & 1 & 0,506 \\
\hline \multicolumn{7}{|l|}{ Consistency Ratio: 0,08 } \\
\hline Rainfall & $\mathrm{R} 1$ & $\mathrm{R} 2$ & R3 & $\mathrm{R} 4$ & R5 & \\
\hline$<700 \mathrm{~mm}(\mathrm{R} 1)$ & 1 & $1 / 2$ & $1 / 3$ & $1 / 4$ & $1 / 5$ & 0.062 \\
\hline $700-750 \mathrm{~mm}(\mathrm{R} 2)$ & & 1 & $1 / 2$ & $1 / 3$ & $1 / 4$ & 0.097 \\
\hline $751-800 \mathrm{~mm}(\mathrm{R} 3)$ & & & 1 & $1 / 2$ & $1 / 3$ & 0.160 \\
\hline $801-850 \mathrm{~mm}(\mathrm{R} 4)$ & & & & 1 & $1 / 2$ & 0.263 \\
\hline$>850 \mathrm{~mm}(\mathrm{R} 5)$ & & & & & 1 & 0.419 \\
\hline \multicolumn{7}{|c|}{ Consistency Ratio: 0,06 } \\
\hline Land use & LU1 & LU2 & LU3 & LU4 & LU5 & \\
\hline Barren areas (LU1) & 1 & $1 / 2$ & $1 / 2$ & $1 / 4$ & $1 / 6$ & 0,063 \\
\hline Urban areas (LU2) & & 1 & $1 / 2$ & $1 / 4$ & $1 / 5$ & 0,087 \\
\hline Forest areas (LU3) & & & 1 & $1 / 2$ & $1 / 3$ & 0,143 \\
\hline Shrubby areas - Natural grasslands (LU4) & & & & 1 & $1 / 2$ & 0,271 \\
\hline Cultivated areas (LU5) & & & & & 1 & 0,437 \\
\hline \multicolumn{7}{|l|}{ Consistency Ratio: 0,01 } \\
\hline Geometry of main discontinuities & D1 & D2 & D3 & D4 & D5 & \\
\hline Drive against (D1) & 1 & $1 / 2$ & $1 / 4$ & $1 / 5$ & $1 / 3$ & 0.057 \\
\hline Drive sideways and vertical (D2) & & 1 & $1 / 3$ & $1 / 4$ & $1 / 2$ & 0.089 \\
\hline Drive with, having a dip of 1-15 (D3) & & & 1 & $1 / 4$ & 3 & 0.235 \\
\hline Drive with, having a dip $16-30^{\circ}(\mathrm{D} 4)$ & & & & 1 & 4 & 0.490 \\
\hline Drive with, having a dip of $>30^{\circ}$ (D5) & & & & & 1 & 0.129 \\
\hline Consistency Ratio: 0,06 & & & & & & \\
\hline
\end{tabular}


Table 2. Weighting coefficients of every parameter involved.

\begin{tabular}{|c|c|c|c|c|c|c|c|}
\hline & $P 1$ & $P 2$ & $P 3$ & $P 4$ & P5 & P6 & Weighting coefficient, $W_{i}$ \\
\hline P1 & 1 & 2 & $1 / 3$ & $1 / 2$ & 3 & 1 & 0,136 \\
\hline $\mathbf{P 2}$ & & 1 & $1 / 3$ & $1 / 2$ & 2 & $1 / 2$ & 0,090 \\
\hline P3 & & & 1 & 2 & 5 & 3 & 0,352 \\
\hline P4 & & & & 1 & 4 & 2 & 0,218 \\
\hline P5 & & & & & 1 & $1 / 6$ & 0,047 \\
\hline P6 & & & & & & 1 & 0,158 \\
\hline \multicolumn{8}{|c|}{ Consistency Ratio: 0,03 } \\
\hline \multicolumn{8}{|c|}{ P1=Lithology, P2=Distance from Tectonic elements, P3= Slopes' inclination } \\
\hline
\end{tabular}

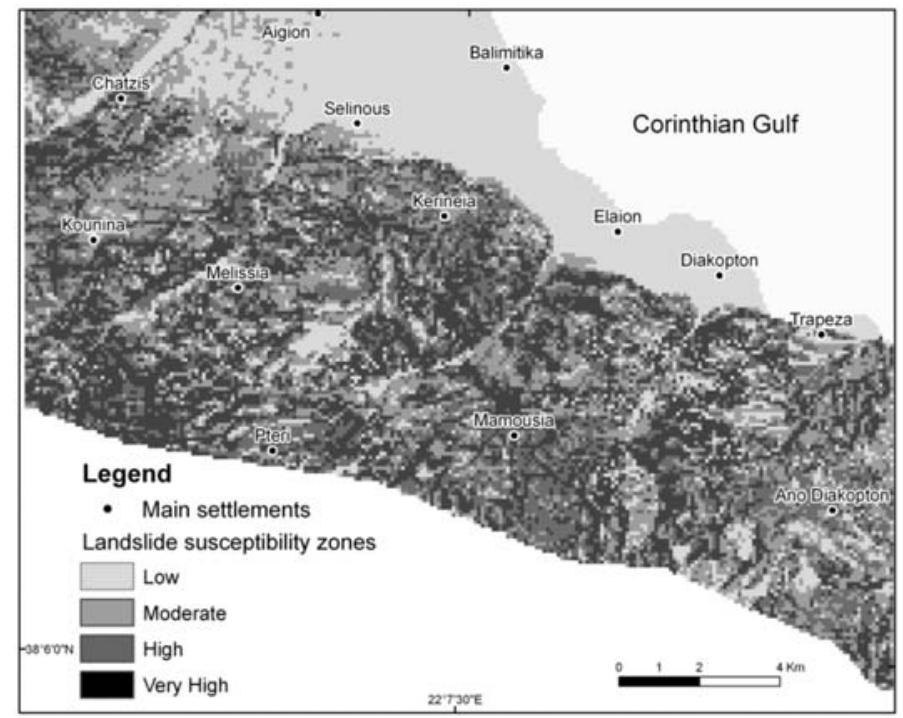

Fig. 4: Landslides susceptibility map

ing of the major parameters affecting landslides and their classes involved are valuable for compilation of a landslide susceptibility maps.

Therefore, AHP, supported by GIS capabilities, helps to the compilation of landslide susceptibility maps. This kind of maps can significantly helps in the urban planning and development of a site, a town or a county. To this direction, the landslide susceptibility map which was compiled during this study can be a useful guide for local Authorities, with regard to landslide confrontation and thus to the restriction of their damages in inhabited areas and technical works.

\section{References}

Akgün, A., Dag, S., Bulut, F., 2008. Landslide susceptibility mapping for landslide-phrone area (Findikli, NE Turkey) by likehood-frequency ratio and weighted linear combination models. Environmental Geology 54, 1127-1143.

Ayalew, L., Yamagishi, H. and Ugawa N., 2004. Landslide susceptibility mapping using GIS-based weigh- 
ted linear combination, the case in Tsugawa area of Agano River, Niigata Prefecture, Japan. Landslides $1,73-81$.

Bathrellos, G.D., Kalivas, D.P., Skilodimou H.D., 2009. Landslide susceptibility mapping models, applied to natural and urban planning, using G.I.S. Jou. Estudios Geológicos 65(1), 49-65.

Bossard, M., Feranec, J., Otahel, J., 2000. CORINE land cover technical guide - Addendum 2000. European Environment Agency, Copenhagen, p 104.

Castellanos Abella, E.A. and Van Westen C.J., 2007. Generation of landslide risk index map for Cuba using spatial multi-criteria evaluation. Landslides, 4, 311-325.

Doutsos, T., Kontopoulos, N., Poulimenos, E., 1988. The Corinth-Patras rift as the initial stage of continental fragmentation behind an active island arc (Greece). Basin Research p177-190.

Guzzetti, F.; Carrara, A.; Cardinali, M. \& Reichenbach, P., 1999. Landslide hazard evaluation: a review of current techniques and their application in a multi-scale study, Central Italy. Geomorphology 31, 181 - 216.

IGME, 2005. Geological Map of Greece, at a scale of 1:50.000, Aigion sheet, Athens.

Komac, M., 2006. A landslide susceptibility model using the Analytical Hierarchy Process method and multivariate statistics in perialpine Slovenia. Geomorphology 74, 17 - 28.

Koukis, G. and Rozos, D., 1982. Geotechnical conditions and landslide movements in the Greek territory in relation to the geological structure and geotectonic evolution. Mineral Wealth 16, 53 - 69.

Koukis, G., Rozos, D., Hatzinakos J., 1997. Relationship between rainfall and landslides in the formations of Achaia county, Greece. Proc. of International Symposium of I.A.E.G. in Engineering Geology and the Environment, A.A. Balkema, Vol.1, pp.793-798, Rotterdam.

Koukis, G., Sabatakakis, N., Nikolaou, N., Loupasakis, C., 2005. Landslides hazard zonation in Greece. Proc of open symp. on landslides risk analysis and sustainable disaster management by International Consortium on Landslides, Washington USA, Chapt 37 pp 291-296.

Lan, HX., Zhou, CH., Wang, LJ., Zhang, HY., Li, RH., 2004. Landslide hazard spatial analysis and prediction using GIS in the Xiaojiang watershed, Yunnan, China. Engineering Geology, 76, 109- 128.

Rozos, D., 1989. Engineering-geological conditions in the Achaia County. Geomechanical characteristics of the Plio-pleistocene sediments. Ph.D. Thesis, University of Patras, 453p. Patras (in Greek, with extensive summary in English).

Rozos, D., Pyrgiotis, L., Skias, S., Tsagaratos, P. 2008. An implementation of rock engineering system for ranking the instability potential of natural slopes in Grek territory. An application in Karditsa County. Landslides 5, 261-270.

Rozos, D., Tsagaratos, P., Markantonis, K., Skias, S., 2006. An application of Rock Engineering System (RES) method for ranking the instability potential of natural slopes in Achaia County, Greece. Proc. of XI In $I$ ternational Congress of the Society for Mathematical Geology, S08-10, University of Liege Belgium.

Saaty, TL., 1990. How to make a decision: The Analytic Hierarchy Process. European of Operational Research 48, 2-26.

Saaty, TL., 2006. Rank from comparisons and from ratings in the analytic hierarchy/ network processes. European of Operational Research 168, 557-570.

Sabatakakis, N., Koukis, G., Mourtas, D., 2005. Composite landslides induced by heavy rainfall in suburban areas. City of Patras and surrounding area, Western Greece. Landslides, Springer Werlag 2:202-211.

Saha, AK, Gupta, RP., Arora, MK., 2002. GIS-based Landslide Hazard Zonation in the Bhagirathi (Ganga) Valley, Himalayas. Int. J. Remote Sensing 23(2), 357 - 369.

Yoshimatsu, H. and Abe, S., 2006. A review of landslide hazards in Japan and assessment of their susceptibility using Analytical Hierarchy Process (AHP) method. Landslides 3, 149 -158. 